\title{
Success and Failure of the Macedonian Entrepreneurs
}

\author{
Snezana Bilic ${ }^{1, *}$, Ljupco Sotiroski ${ }^{2} \&$ Borka Tusevska $^{2}$ \\ ${ }^{1}$ Faculty of Economics and Administrative Sciences, International Balkan University, 1000 \\ Skopje, Republic of Macedonia \\ ${ }^{2}$ Faculty of Law, University “Goce Delcev”, 2000 Stip, Republic of Macedonia \\ *Corresponding author: Faculty of Economics and Administrative Sciences, International \\ Balkan University, Str. Tashko Karadza No. 11A, 1000 Skopje, Republic of Macedonia. \\ E-mail: sbsbilic@gmail.com
}

Received: May 4, 2014 Accepted: July 4, 2014 Published: August 28, 2014

doi:10.5296/rae.v6i3.5580ＵRL: http://dx.doi.org/10.5296/rae.v6i3.5580

\begin{abstract}
The aim of this paper is to investigate the cases of success and failure of the Macedonian entrepreneurs. In an online survey, entrepreneurs were asked to recall experiences of success and failure date these experiences and assess how much they learnt as a result. The Results show interesting regularities about the timing of success versus failure. Consistent with the extant literature on learning from experience, conclusion is made that entrepreneurs learn more from failure then from success. From the results can be concluded that entrepreneurs considered the success events to be more relevant for their careers than the failure events Macedonian entrepreneurs percept attribute of success to internal factors, whereas they attribute of failure to external factors. The entrepreneurship in the Republic of Macedonia needs designed projects to support transition to a free market-based economics, to develop democratic institutions, to educate entrepreneurs and to encourage them to start - up their own business.
\end{abstract}

Keywords: Entrepreneurs, Success, Failure, Macedonia 


\section{Introduction}

Entrepreneurship is the new phenomena for Macedonian economy. Since its independence in 1991, the Republic of Macedonia paves the way towards market oriented economy. In this process the country was supported by many donors, which transfer their best knowledge and practices. According to the data from USA Embassy in Skopje (Press Released, 24.09.2007), the American people, through USAID, have invested more than \$450 million in Macedonia since 1993 and more than 20 projects, worth \$30 million a year, are currently being implemented.

With the recent economic reforms, Macedonia has created the most attractive tax package in Europe. These reforms include introduction of flat tax rate of $10 \%$ for corporate and personal income, which simplify the tax system and stimulate successful companies to further improve operations and increase profitability.

Market freedom, the freedom of entrepreneurial activity, as well as property rights are guarantee with the Constitution of the Republic of Macedonia. The Company Law is the primary law regulating business activity in Macedonia. This legal framework includes the One-Stop-Shop system that reduced administrative barriers for establishment a company within 4 hours of submission of documentation and electronic distribution service that allows any potential investor or third party to obtain complete electronic information about the operations of companies in the country.

In direction of creation of positive business climate several incentives were made in the Law on Investment Funds, Law on Competition, The Law Against Unfair Competition and Law on Environment.

These reforms as recognition for the success and were confirmed by the World Bank Report “Doing Business 2013". According to this report (IFC, 2013), Macedonia for the overall indicator of "simplicity in doing business" is ranked on the 23th place in competition of 185 countries from the world.

Starting from 2007, in Republic of Macedonia, the traditional event Entrepreneur of the Year is organized. Its goal is promotion of the most successful entrepreneurs of micro and small enterprises in Republic of Macedonia for the ongoing year.

The country continues to have high levels of unemployment, where entrepreneurship is still necessity, not opportunity. The long-term potential for those unemployed people to become economically productive is there, but remains untapped.

The first survey on entrepreneurship in Macedonia was prepared in 2008, (GEM National Team for Macedonia) and showed relatively high indices of entrepreneurship in Macedonia.

According to the conclusion from Entrepreneurship in Macedonia (GEM Report, 2009), the youngest population (from 18 to 24) is significantly more prone to entrepreneurship compared to the countries from the region. "Young business people may dip their fingers into some business venture, but at the first signs of trouble run and never try again”. (Emerging Macedonia, 2011) 
Concerning the education and training of the entrepreneurs, in September 2007 the USAID supported creation of the Center for Entrepreneurship and Executive Development as a unique training center. It addresses specific entrepreneurial growth needs in short, high impact courses that fit the schedules of busy executives. According to the US Ambassador in Macedonia, Ms. Gillian Milovanovic "Current available training programs are too lengthy, insufficiently practical and applicable, and are not designed for today's busy entrepreneurs and executives. Macedonian young, growing entrepreneurs and managers now will have the opportunity to attend practical, interactive courses based on mentoring and peer-to-peer trainings.” (Press Release, 2007)

According to the last national GEM Report for Macedonia (2009) the entrepreneurial perceptions are mainly positive. Almost every second respondent feels that there will be good opportunities for starting a business in the next 6 months, personally knows someone who started a business and feels that he/she has the required knowledge and skills to start a business. $80 \%$ consider entrepreneurship as a desirable career choice and $66 \%$ feel that the media pay sufficient attention to entrepreneurship. Only 35\% state that fear of failure would prevent them from starting a business whereas $40 \%$ expect to start a business in the next 3 years.

Macedonia has the highest entrepreneurial activity from the countries in Europe where the GEM study was undertaken, measured through the key index TEA (Total Early-stage Entrepreneurial Activity). The TEA index for Macedonia is $14.5 \%$ and is higher than in EU and OECD countries, as well as compared to the countries from the region. It means that $14.5 \%$ from the respondents at age of 18-64 are entrepreneurs. Half of these are nascent entrepreneurs (involved in business activities up to 3 months) whereas half are new entrepreneurs (involved in business activities up to 3.5 years). Still, half of the entrepreneurs from Macedonia are entrepreneurs because of necessity whereas the other half is consisted of entrepreneurs motivated by opportunity. The gap between male and female entrepreneurs in Macedonia is slightly larger in favor of male, compared to the level of the countries from the region. (GEM Report, 2009).

\section{Literature Review}

The literature on learning from experience shows that important differences exist in how people learn from experiences of success and failure.

First, individuals seem to attribute successes and failures to very different causes. In a recent study, Moen and Skaalvik (2011) conducted an experiment among top executives which concluded that success is more likely attributed to strategy, effort and ability, as opposed to chance. As for failures, it has been found that failures too are often attributed to strategy, however they are a lot less likely to be linked to ability. The study found that executives tend to take credit for achievement by attributing achievement to factors under their control. On the other hand, when facing setbacks, executives tend to self-justify, attributing failure to external factors or to lack of effort on the part of their subordinates. However, when failures 
are attributed to external factors, the probability of further success may decrease (Moen \& Skaalvik, 2011). In fact, additional evidence shows that future growth of projects can be maximized if the external environment is not considered to be the cause of setback (Yamakawa, Peng, \& Deeds, 2010). In this sense, understanding what the main internal factors that led to failure are can offer more precise insights on how to have higher chances of succeeding in the future (Yamakawa et al., 2010).

At the same time, Ellis and Davidi (2005) show that while failures catalyze epistemic processes such as hypothesis generation and information acquisition, successes tend to limit such processes. Based on a conducted experiment, the authors found that people tend to focus more on finding the reasons for failure than for successes. Moreover, the findings of this study corroborated previous results which showed that people focus on searching for explanation-relevant information when unanticipated events occur (Hastie, 1984; Wong \& Weiner, 1981). Given the prevalence of optimism among entrepreneurs (Puri \& Robinson, 2006), success is more likely to be anticipated, whereas failures are more likely to be unanticipated. Ellis and Davidi (2005) find that people have more complex mental plans to explain failure, with longer causal paths and explanations, compared to how they reason about successes. Gino and Pisano (2011) point out that one of the difficulties of learning from success is exactly this so-called "failure-to-ask-why" syndrome, following the experiences of success.

In the specific case of entrepreneurs, experiencing events of success and failure can have consequences of considerable magnitude to both the entrepreneur and the community in which he or she operates. As an example, a study conducted in 1995 in the USA showed that half of the projects in the area of information systems failed, with total costs of these failures reaching \$140 billion (Keil \& Robey, 1999). Nevertheless, entrepreneurship researchers argue that project failures provide precious opportunities to learn from experience and improve in the future (McGrath, 1999). According to Minniti and Bygrave (2001), by learning from past experience, entrepreneurs may even increase their probabilities of reaching success in subsequent business projects. This idea of learning from failure is also shared by Timmons (1994), who argues that in order to be successful an entrepreneur has to fail first. The author also refers to the pattern which shows that when the first business endeavor fails, the entrepreneur tends to later launch a very successful company.

Entrepreneurship researchers also discuss emotional reactions to events of success and failure, and how emotional reactions may affect what can be learned from these experiences. According to Shepherd and Cardon (2008), individuals are better prepared to learn from negative emotional reactions to failures if they are able to show self-compassion in the form of self-kindness, common humanity and mindfulness. Additionally, Shepherd (2003) argues that the emotional response to the loss of own business may interfere with further experiences. In order to minimize the negative impact of the emotional reaction, Shepherd (2003) argues that "entrepreneurs should balance between a loss-orientation process and a restoration-orientation process” (p.275). 
Emotional reactions to past experience and their consequences are also discussed by Ucbasaran, Westhead and Wright (2011). These authors analyze the concept of overoptimism, which is defined as "the tendency to believe that one is more likely than others to experience positive events and less likely to experience negative ones” (Ucbasaran, Westhead, \& Wright, 2011, p.1). The authors support the idea that this tendency can be extremely positive when bringing the projects to the start-up level. However excess of confidence can also lead to business negligence. In order to minimize this tendency among entrepreneurs to feel "unbeatable", failures may be useful. Facing failures can mitigate this surplus of optimism and increase the odds of future success (Ucbasaran, Westhead, \& Wright, 2011).

Despite of all the literature reviewed, to our knowledge, no previous research examined the differences in how entrepreneurs learn from success and failure. Or even, what successes and failures are relevant to entrepreneurial learning, other than project successes and failures.

\section{Research Methodology and Analysis}

The main focus of the study is to understand the relation between types of successes and failure and the learning process inherent. Considering this fact, this study will answer the following Research Questions:

- What types of success and failure did Macedonian entrepreneurs experience during their career?

- When do successes and failures occur during the career span of an Macedonian entrepreneur?

- How much is learned from success and from failure?

Judgmental sampling method was used for online survey done in the period of April - May 2013, in the Republic of Macedonia, mostly in the area of Stip. 95 employees were invited to participate in an online survey regarding entrepreneurs and their careers. $50 \%$ of the entrepreneurs responded to the invitation, but the final response rate was $42 \% .90 \%$ of the final sample $(\mathrm{N}=40)$ was male, with an average age of $46.44 \%$ had a university degree at a minimum, including $48 \%$ who had completed a graduate studies. The average duration of the entrepreneurial career was 16 years on average, with about 5 years of pre-entrepreneurship experience in the same industry.

Participants completed an online survey. Considering the structure, the survey was composed by 17 different sections.

\subsection{Initial Conditions}

Entrepreneurs were asked to assess conditions of the external environment at the time when their first company began operations. They expressed their degree of agreement with each of the items on a $1-5$ scale ( 1 = strongly disagree; 5 = strongly agree). The 15 Items included "It was a time of economic boom/prosperity" and "The failure rate of firms in my industry was high, among others (Chronbach’s alpha = .553). 


\subsection{Learning on Different Career Stages}

Entrepreneurs were required to provide some information on the different stages of career that they have been through. In this sense, the entrepreneurs needed to report in which career stage they were (Beginning, Middle or Later). One of the required information was for the respondents to state how much did they learn in the different phases, on a 1-5 scale (1= Very Little; 2 = Little; 3 = Somewhat; 4 = A lot; 5 = A great deal).

\subsection{Companies Founded and Bankruptcy}

Entrepreneurs were asked to report the foundation of up to five companies, on a chronological way. Additionally, they were requested to report the occurrence in time (or not) of bankruptcy of their companies.

\subsection{Successes and Failures}

A series of measures on successes and failures was considered in order to better understand these events reported by entrepreneurs. It should be highlighted that all entrepreneurs were asked to describe successes and failures in their own words.

\subsection{Occurrence in Time}

Entrepreneurs were asked to situate in time an event of success and failure of their entrepreneurial career. When required to recall different events of successes and failures, entrepreneurs needed to define whether they attributed them to internal or external conditions.

\subsection{Internal/External Environment}

Entrepreneurs were asked to state how favorable were the internal and external environment by the time of the occurrence of the events of success and failure, on a 1-5 scale (1 = Extremely Unfavorable, 2 = Unfavorable, 3 = Not Sure, 4 = Favorable, 5 = Very Favorable).

\subsection{Learning from Success and Failure}

The measures considered on learning from success and failure target at a deeper understanding of how knowledge is acquired and influenced.

\subsection{Importance of Lessons Learnt}

The entrepreneurs were asked to state if the reported success and failures provided an important lesson and if they considered them turning points for their careers, on a Yes or No answer.

\subsection{Successes and Failures as Turning Points}

Entrepreneurs were asked to answer to what extent did they agree with the events of success and failure being turning points of their careers, on a 1-5 scale $(1=$ Not at all, $2=$ To a small extent, 3 = Somewhat, 4 = Quite a bit, and 5 = Absolutely). 


\section{Macrothink}

Research in Applied Economics

ISSN 1948-5433

2014, Vol. 6, No. 3

\subsection{Knowledge Acquired from Success and Failure}

Entrepreneur were asked to answer to what extent did they agree with a list of items regarding how their knowledge improved based on the recalled events of success and failure, on a $1-5$ scale ( 1 = strongly disagree; 5 = strongly agree). Four Indexes were created, for both events of success and failure: Overall Knowledge Index (all items considered), Management Index ("Product/Service”, “Strategy”, “Marketing”, and "Logistics”), Finance Index ("Finance”, "Fund Raising”, and "Cash Management”), and Relationship Index ("People and Relationships”, “Human Resource Management”, and “Networking”). For either Success or Failure, Chronbach's Alpha for all indexes was higher than .87)

\subsection{Life Conditions}

Knowledge acquired was evaluated according to this measure explained previously.

\subsection{Initial Knowledge}

The entrepreneurs were asked to answer to what extent did they agree with a list of statements regarding what their knowledge at the start of their career as an entrepreneur when their first company began operations, on a 1-5 scale $(1=$ strongly disagree; $5=$ strongly agree). The same indexes as the Knowledge acquired from success and failure were computed, with Chronbach's Alpha always higher than .86.

\section{Findings}

Overall career characteristics shown that on average, entrepreneurs created 1.4 companies throughout their careers. A variety of industries was represented, including Architecture and Engineering, Building and Ground Maintenance, Transportation and Material Moving, Production, Business and Financial Activities, Service Related and Others. It took 5 years on average from the creation of the first company to the creation of the second company, 2 years from the creation of second company to the creation of the third company. The fourth company was created only by one respondent after 6 years.

$30 \%$ of entrepreneurs had a mentor who helped them establish their first company. $20 \%$ had a business plan for their first company. Entrepreneurs' assessment of their initial conditions followed a normal distribution ( $\mathrm{M}=3.16, \mathrm{~S}=.35$ ), according to the Shapiro-Wilk test ( $\mathrm{S}(40)$ $=.98, \mathrm{p}=.79$ ), e.g. Figure 1 . 


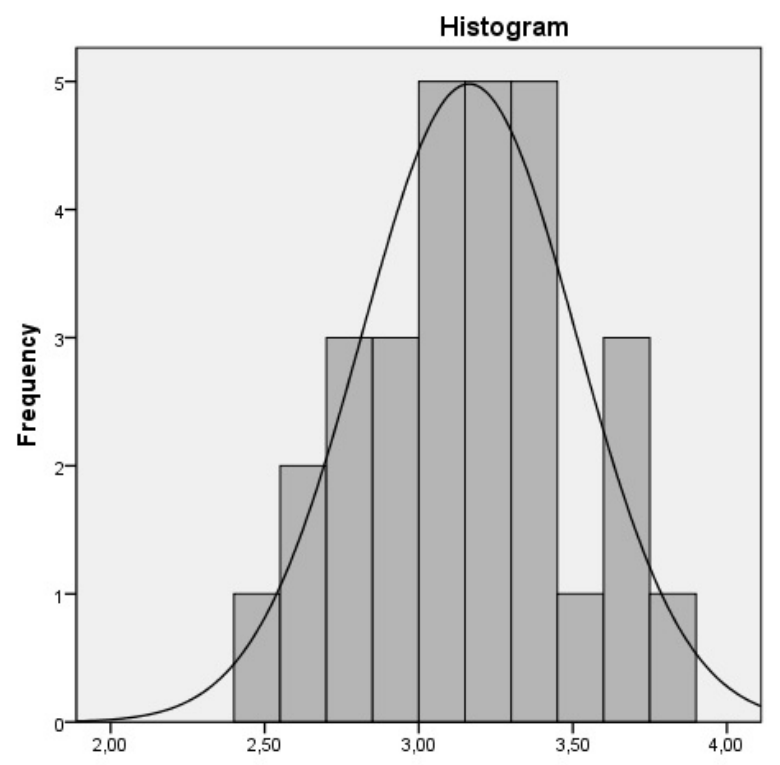

Figure 1. Histogram for Average Initial Conditions

In terms of self-report career stage, 11entrepreneurs reported to currently experience the early stage of their career, 13 reported to currently experience the middle stage of their career and 16 to be in the late stage of their career. On average, the early career stage was estimated to last for 9 years, the middle career stage was estimated to last for 7 years, and the late career stage was estimated to last for 4 years. Also, entrepreneurs anticipated to remain active for 18 years on average, in which they expected to be able to create 2.4 new companies.

Of all founded companies, $60 \%$ was reported to occur during what the entrepreneurs defined as their "early career stage", $14 \%$ was reported to occur during what the entrepreneurs defined as their "middle career stage", and $26 \%$ as their "late career stage”. Of all founded companies, only 1 was reported to have gone bankrupt, and this was with the second company.

From reported success, the examples provided were varied and included more detailed explanations. Some examples of experiences reported included the launching of a new product, entering into the new markets, new partnership agreements with foreign partners and reduction of the costs of production. For example, respondent no. 15 writes "Decreasing of the costs in one of the production plants, from 2 shifts to 1 shift, we kept the production on the same level, but decreased the costs for 30\%" and respondent no. 27 "launching a product which was accepted by the Balkan countries markets”, as the recalled success. 
Table 1. Typology of Success Events

\begin{tabular}{ll}
\hline Reported Success Events & Percentage of N \\
\hline Launching a new product & $14.8 \%$ \\
Entering into the new market & $37.0 \%$ \\
New partnership agreements & $33.4 \%$ \\
Reduction of costs of production & $7.4 \%$ \\
Others & $7.4 \%$ \\
\hline
\end{tabular}

As it is shown in the Table 1. all reported success events by the entrepreneurs are result of the internal organizational factors.

For failure, the examples provided were varied but often on included detailed explanations. For instance, one entrepreneur recalls (respondent no. 4): "Leaving my company's' employee, who is well acquainted with the business and the opening of a competitive firm "Another entrepreneur (respondent no. 13) writes "Going into a business that was not very familiar to us. We bought complete line for one type of food production, but we still have problems in returning our investment". Also there were respondents who did not have experience with failure events.

Table 2. Typology of failure events

\begin{tabular}{ll}
\hline Reported Failure Events & Percentage of N \\
\hline Termination of contracts & $18.5 \%$ \\
Wrong business plan and wrong product investments & $22.2 \%$ \\
Bad inter-personal relations with partners and employees & $14.8 \%$ \\
Drop-out of employees in the competitive companies & $14.8 \%$ \\
Non Loyal competition & $7.4 \%$ \\
No previous business experience & $14.9 \%$ \\
No failure events occurred & $7.4 \%$ \\
\hline
\end{tabular}

All reported failure events by the entrepreneurs listed in the Table 2 are more or less result of the external environmental factors.

Timing of all reported successes, 54\% was reported to occur during what the entrepreneurs defined as their "early career stage, $20 \%$ was reported to occur during what the entrepreneurs defined as their "middle career stage", and $26 \%$ as their "late career stage".

Of all reported failures, 38\% was reported to occur during what the entrepreneurs defined as their "early career stage, $23 \%$ was reported to occur during what the entrepreneurs defined as their "middle career stage", and 39\% as their "late career stage”.

According to the results obtained concerning importance of lessons learnt, $90 \%$ of entrepreneurs reported to have learnt an important lesson from their success event. Regarding failures, $85 \%$ of entrepreneurs recalled this type of event with the provision of an important lesson.

The average agreement on the success being a turning point was 3.8, while for failures this 
value was 2.8. From these results one can understand that the respondent entrepreneurs considered the success events to be more relevant for their careers than the failure events.

According to the results for knowledge acquired, entrepreneurs reported on average to have learnt more from first success than from first failure. When analyzing the different indexes individually, it is interesting to verify that the one who presents a sharper difference is the one related to Management Issues. Moreover, knowledge on People-Related issues was reported to be the one which mostly improved after both first success and failure.

In order to verify if there was significant statistical difference between the average acquirement of knowledge from first success and failure, Paired-Sample T-Tests were run on the different indexes.

The conducted tests allowed reaching the following confirmations:

Overall acquired learning from first success $(\mathrm{M}=3.98$; $\mathrm{SD}=.54)$ was reported to be significantly higher than Overall acquired learning from first failure $(\mathrm{M}=3.64$; $\mathrm{SD}=.91)$, $\mathrm{t}(39)=2.5, \mathrm{p}<.05$.

Knowledge acquired on People-Related Issues from first success $(\mathrm{M}=4.01$; $\mathrm{SD}=.66$ was reported to be higher than the Knowledge acquired on People-Related Issues from first failure $(\mathrm{M}=3.76 ; \mathrm{SD}=1.07), \mathrm{t}(39)=1.44, \mathrm{p}=\mathrm{n} . \mathrm{s}$, but not significantly.

Knowledge acquired on Management-Related Issues from first success ( $M=3.98$; $S D=.53$ ) was reported to be significantly higher than the Knowledge on Management-Related Issues from first failure $(\mathrm{M}=3.46$; $\mathrm{SD}=1.01), \mathrm{t}(39)=2.88, \mathrm{p}<.01$.

On average, Knowledge acquired on Financial-Related Issues from first success ( $\mathrm{M}=3.67$; $\mathrm{SD}=.97)$ and Knowledge acquired on Financial-Related Issues from first failure $(\mathrm{M}=3.26$; $\mathrm{SD}=1.22$ ) did not differ significantly, $\mathrm{t}(39)=1.53$, $\mathrm{p}=$ n.s..

The next step of analysis was related to the knowledge acquired by the entrepreneurs, but considering their life conditions at the time of the reported success and failure.

On this phase of analysis, it was decided to divide the sample into two groups. The first one included those who reported to live with positive life conditions (Excellent, Good and Fair), and the second group included those entrepreneurs who lived with negative life conditions (Poor and Very Poor. Under the explained restrictions, $72 \%$ of the entrepreneurs were reported to have positive life conditions and $28 \%$ reported to have negative life conditions.

The results presented showed that, regardless of life conditions and type of issue, the knowledge acquired from first success was superior to the one acquired from first failure. Under Positive Life Conditions, entrepreneurs reported to have learnt more on People-Related Issues from first success and failure. Considering Negative Life Conditions, entrepreneurs reported to have learnt more on Financial-Related issues on both first success and failure.

Comparing the two groups, it can be perceived that knowledge acquired on Financial-Related issues from first success and first failure were the only cases where entrepreneurs living with 
negative life conditions learnt more.

\section{Conclusion}

Republic of Macedonia is characterized as transitional country, in the process of moving from a closed to an open market economy while building accountability within the system. As an emerging market, a country is embarking on an economic reform program that will lead it to stronger and more responsible economic performance levels. So, the entrepreneurship is a new phenomena developed in the last 20 years. .

The profile of entrepreneurs is dominantly male, with the average age of 46.02. The life conditions of the entrepreneurs have been significantly enhanced comparing the data of yearly income of the entrepreneurs from the early stage to the current period.

Concerning previous working experience the Macedonian entrepreneurs spent the average of 4.84 years in the same industry, with the overall previous experience of 7.15 years. In case of Macedonia, the number of successes reported, the number of failures reported and the number of bankruptcy reported is limited, due to the fact that Macedonian entrepreneurs modestly founded on average 1.38 companies.

Macedonian entrepreneurship needs designed projects to support transition to a free market-based, multi-ethnic economy, including initiatives to accelerate economic growth, develop democratic institutions, educate entrepreneurs and encourage them to start - up their own business.

\section{Limitation and Future Research}

The study was conducted with limited sample size as respondents, with limited coverage of the events over career span and social desirability biases. Future research can be conducted with increase qualitative analysis for successes and failures and additional questions for more events of success / failure and internal conditions.

\section{References}

Ellis, S., \& Davidi, I. (2005). After-Event Reviews: Drawing Lessons from Successful and Failed Experience. Journal of Applied Psychology, 90, 857-871. http://dx.doi.org/10.1037/0021-9010.90.5.857 90

Emerging Macedonia, (2011). Learning from Failure; Business failure - a stepping stone to success; issue $\quad 3 . \quad$ Retrieved January 12, 2014 from http://amcham.com.mk/wbstorage/files/autumn2011.pdf

GEM National Team for Macedonia, (2008). Entrepreneurship in Macedonia, Macedonian Enterprise Developing Foundation. Retrieved November 24, 2013 from 
http://www.gemconsortium.org/docs/download/557

Gino, F., \& Pisano, G.P. (2011). Why Leaders Don’t Learn from Success. Harvard Business Review, 89(4), 68-74.

Keil, M., \& Robey, D. (1999). Turning Around Troubled Software Projects: An Exploratory Study of the De-escalation of Commitment to Failing Courses of Action. Journal of Management Information Systems, 15(4), 63-88.

McGrath P.A. (1999). Chronic Pain in Children. In: Crombie, I. Croft, P. Linton, S. Le Resche, L. Von Korff, M. (Eds). Epidemiology of Pain. Seattle: IASP Press, 81-101.

Minniti, M., \& Bygrave, W. (2001). A Dynamic Model of Entrepreneurial Learning. Entrepreneurship: Theory and Practice, 25(3), 5-16.

Moen, F., \& Skaalvik, E. (2011). Causal Attributtion among Business Executives Investigation. The Journal of Excellence, 15, 40-59.

Program for Development of Entrepreneurship, Competitiveness and Innovativeness of the Small and Medium-sized enterprises 2011-2013, Agency for promotion of the entrepreneurship of the Republic of Macedonia.

Puri, M., \& Robinson, D.T. (2006). Who are Entrepreneurs and Why Do They Behave that Way. Working Paper. Duke University and NBER.

Shepherd, D. A. (2003). Learning from Business Failure: Propositions of Grief Recovery for the Self-Employed. Academy of Management Review, 28(2), 275.

Shepherd, D. A., \& Cardon, M. S. (2008). Negative Emotional Reactions to Project Failure and the Self-Compassion to Learn from Failure Experience. Working paper, Indiana University.

Timmons, J.A. (1994). New Venture Creation: Entrepreneurship for the 21st Century. Boston: McGraw-Hill/Irwin.

Ucbasaran, D., Westhead, P., \& Wright, M. (2011). Why Serial Entrepreneurs Don't Learn from Failure. Harvard Business Review, 89, 26-2.

USA Embassy in Skopje (Press Released, 24.09.2007). Top Class for Macedonian Entrepreneurs, The Centre for Entrepreneurship and Executive Development (CEED Macedonia). $\quad$ Retrieved April 7, 2013 from http://macedonia.usembassy.gov/ceed_event.html

Wong, P.T.P., \& Weiner, B. (1981). When People Ask "Why” Questions, and The Heuristics of Attributional Search. Journal of Personality and Social Psychology, 40, 650-663.

World Bank Report (2013). “Doing Business 2013”, IFC, p.3.

Yamakawa, Y, Peng, M.W., \& Deeds, D.L. (2010). Revitalizing and Learning from Failure for Future Entrepreneurial Growth. Frontiers of Entrepreneurship Research, 30(6), Article 1. 


\section{Mll Macrothink}

Appendix1 Descriptive Statistics

\begin{tabular}{|c|c|c|c|c|c|c|c|c|c|c|c|c|c|c|c|c|}
\hline & & $\mathrm{M}$ & SD & 1 & 2 & 3 & 4 & 5 & 6 & 7 & 8 & 9 & 10 & 11 & 12 & 13 \\
\hline 1 & Gender $(0=\mathrm{F} ; 1=\mathrm{M})$ & .90 & .29 & - & & & & & & & & & & & & \\
\hline 2 & Age & 46.02 & 12.42 & .10 & - & & & & & & & & & & & \\
\hline \multirow[t]{2}{*}{3} & FirstCompany - Marital status ( 1 = Married and In & & & & & & & & & & & & & & & \\
\hline & a Relationship; 0 = otherwise) & .49 & .50 & -.172 & .21 & - & & & & & & & & & & \\
\hline \multirow[t]{2}{*}{4} & Currently - Marital status ( 1 = Married and In a & & & & & & & & & & & & & & & \\
\hline & Relationship; 0 = otherwise) & .51 & .49 & $-.321^{*}$ & .194 & $.855^{* *}$ & - & & & & & & & & & \\
\hline 5 & FirstCompany - Yearly Income & .84 & .89 & -.064 & .036 & $.632^{* *}$ & $.642^{* *}$ & - & & & & & & & & \\
\hline 6 & Currently - Yearly income & 2.08 & 2.05 & -.113 & $.151^{*}$ & $.672^{* *}$ & $.647^{* *}$ & $.726^{* *}$ & - & & & & & & & \\
\hline \multirow[t]{2}{*}{7} & FirstCompany - Education ( 1 = Grad School; 0 = & & & & & & & & & & & & & & & \\
\hline & Below Grad School) & .44 & .87 & -.034 & .165 & $.550^{* *}$ & $.513^{* *}$ & .559 & $.490^{* *}$ & - & & & & & & \\
\hline 8 & $\begin{array}{l}\text { Currently - Education }(1=\text { Grad School; } 0= \\
\text { Below Grad School) }\end{array}$ & .48 & .49 & -.206 & .232 & $.513^{* *}$ & $.667^{* *}$ & $.674^{* *}$ & $.486^{* *}$ & $.628^{* *}$ & - & & & & & \\
\hline 9 & $\begin{array}{l}\text { Previous work experience in same industry } \\
\text { (Years) }\end{array}$ & 4.84 & 5.06 & -.013 & -.023 & -.262 & -.175 & -.280 & -.260 & -.193 & -.212 & - & & & & \\
\hline 10 & Overall Previous Experience (years) & 7.15 & 5.75 & .129 & .071 & -.130 & -.131 & .017 & -.042 & -.187 & .105 & -.244 & - & & & \\
\hline 11 & Overall_knowledge_atstart & 3.25 & .78 & .132 & -.072 & -.212 & -.102 & -.230 & -.133 & $-.345^{*}$ & -.165 & .242 & .142 & .891 & & \\
\hline 12 & PeopleIndexKnowledge & 3.25 & .85 & -.068 & .040 & -.173 & -.082 & -.132 & -.059 & -.171 & -.076 & $.342^{*}$ & -.151 & $.631^{* *}$ & .867 & \\
\hline 13 & FinanceIndexKnowledge & 2.23 & 1.83 & .083 & .257 & .013 & .005 & -.232 & -.009 & -.081 & -.120 & .228 & -.105 & .290 & .238 & .923 \\
\hline
\end{tabular}
$N=40$

Note: ${ }^{*} . p<.05 \quad$ **. $p<.01$ 


\section{Macrothink}

\section{Descriptive Statistics}

\begin{tabular}{|c|c|c|c|c|c|c|c|c|c|c|c|c|c|c|c|c|c|c|c|}
\hline & & M & SD & 1 & 2 & 3 & 4 & 5 & 6 & 7 & 8 & 9 & 10 & 11 & 12 & 13 & 14 & 15 & 16 \\
\hline 1 & Gender & .90 & ,29 & - & & & & & & & & & & & & & & & \\
\hline 2 & Age & 46,02 & 12.42 & -.19 & - & & & & & & & & & & & & & & \\
\hline 3 & User_Entrepreneur (1=Yes; 0 =No) & .20 & .40 & .19 & .09 & - & & & & & & & & & & & & & \\
\hline 4 & Companies_Founded & 1.38 & .64 & .11 & .30 & -.04 & - & & & & & & & & & & & & \\
\hline 5 & Average_Cofounders & 3.22 & 1.39 & a & .51 & .32 & .24 & - & & & & & & & & & & & \\
\hline 6 & Use_of_IP (1=Yes; 0=No) & .40 & .50 & -.07 & -.02 & .12 & .28 & -.24 & - & & & & & & & & & & \\
\hline 7 & Number Successes Reported & 1.13 & 1.14 & .11 & .21 & -.06 & $.33 *$ & $.80^{*}$ & .32 & - & & & & & & & & & \\
\hline 8 & Number Failures Reported & .73 & .55 & .14 & .25 & .08 & .29 & -.18 & $.50 *$ & $.55^{*}$ & - & & & & & & & & \\
\hline 9 & Bankrupcy (1=Yes; 0=No) & .03 & .16 & .05 & .17 & -.09 & -.05 & a & -.13 & .13 & .08 & - & & & & & & & \\
\hline 10 & $\begin{array}{l}\text { Lessons First Success Reported } \\
(1=\text { Yes; } 0=\mathrm{No})\end{array}$ & .68 & .47 & .30 & .16 & .031 & .23 & .09 & $.35^{*}$ & $.55^{*}$ & $.73 *$ & .11 & - & & & & & & \\
\hline 11 & PastOrientation & 3.32 & .59 & .21 & .18 & .03 & -.29 & .28 & -.01 & -.01 & .08 & .05 & .13 & .13 & & & & & \\
\hline 12 & PresentOrientation & 4.49 & .53 & -.23 & .11 & -.20 & -.04 & .11 & .07 & .03 & .07 & .02 & -.36 & .21 & .49 & & & & \\
\hline 13 & Future Orientation & 4.30 & .79 & .26 & -.01 & -.11 & .08 & -.02 & .01 & .09 & .25 & .05 & .05 & .31 & $.53^{* *}$ & .85 & & & \\
\hline 14 & Overall Optimism & 4.04 & .42 & .13 & .10 & -.15 & .04 & -.09 & -.09 & .02 & .23 & .05 & .06 & $.63^{* *}$ & $.75^{* *}$ & $.87^{* *}$ & .65 & & \\
\hline 15 & Future ProfYears & 18.85 & 9.52 & -.32 & $-.43^{*}$ & .07 & -.07 & -.09 & .20 & .02 & -.23 & -.31 & -.25 & -.02 & .09 & .15 & .11 & - & \\
\hline 16 & Future Founded Companies & 2.41 & 1.21 & -.02 & $-.47 * *$ & -.01 & .07 & -.14 & .17 & .07 & -.25 & -.21 & -.24 & $-.47 * *$ & .06 & .10 & -.10 & $.43^{* *}$ & - \\
\hline
\end{tabular}

$N=40$

Note: ${ }^{*} . p<.05 \quad{ }^{* *} . p<.01$, a. Cannot be computed because at least one of the variables is constant.

\section{Copyright Disclaimer}

Copyright reserved by the author(s).

This article is an open-access article distributed under the terms and conditions of the Creative Commons Attribution license (http://creativecommons.org/licenses/by/3.0/). 